\title{
Host-plant location by the Guatemalan potato moth Tecia solanivora is assisted by floral volatiles
}

\author{
Miriam Frida Karlsson ${ }^{1,2}$ (1) Magali Proffit ${ }^{1,3} \cdot$ Göran Birgersson $^{1}$
}

Received: 18 May 2017/ Accepted: 19 August 2017 / Published online: 29 August 2017

(c) The Author(s) 2017. This article is an open access publication

\begin{abstract}
Insects locate their host plants using mainly visual and olfactory cues, generally of the exploited plant structure. However, when the resource is difficult to access, it could be beneficial to utilise indirect cues, which indicates the presence of reward (e.g., oviposition site or mate). In the present study, we investigated the host-plant location strategy of the monophagous Guatemalan potato moth Tecia solanivora (Lepidoptera: Gelechiidae). The larva of the moth feed exclusively on potato Solanum spp. (Solanaceae) tubers usually hidden below ground. Using electrophysiological and behavioural tests, we characterised the olfactory cues mediating the attraction of the moth towards their host plant. Odour blends were made to represent different potato structures: tubers, foliage, and flowers. Synthetic blends were created by combining potato-emitted compounds that were antennal active which showed positive dose-response. Attraction to these blends of compounds in relation to the mating status of males and females was tested in dual-choice Y-tube assays. Both males and females, virgin and mated, were attracted to a three-compound blend representing flower odour, while foliage and tuber blends attracted neither sexes.
\end{abstract}

Handling Editor: Thomas Schmitt.

Miriam Frida Karlsson

Miriam.Karlsson@slu.se

1 Department Plant Protection Biology, Swedish University of Agricultural Science, P.O. Box 102, 23053 Alnarp, Sweden

2 International Institute of Tropical Agriculture (IITA), 08 BP 0932 Tri Postal, Cotonou, Benin

3 Centre d'Ecologie Fonctionnelle et Evolutive (CEFE), UMR 5175, CNRS, Université de Montpellier, Université Paul Valéry Montpellier, EPHE, 1919 route de Mende, 34293 Montpellier, France
Oviposition bioassays indicated additionally that the floral blend enhances oviposition. We show that potato flower odour might indicate the presence of an oviposition site for the female and possibly an increased mating opportunity for both sexes. Our results provide one of the few examples of the use of floral odour as a reliable indicator of host and probably mating possibility for phytophagous insects exploiting a site spatially separated from the flower.

Keywords Attraction - Gelechiidae - Kairomone · Olfactometer $\cdot$ Solanum tuberosum

\section{Introduction}

Host seeking behaviour in insects involves a sequence of actions, where the insect has to make a decision whether to continue with, or abandon the search. The insect acceptance of the host is dependent on the phenological and health status of the host plant (Masante-Roca et al. 2007; Dötterl et al. 2009), expressed partly as a release of specific volatile compounds (Jhumur et al. 2006; Tasin et al. 2007) or ratio of such compounds (Grison-Pigé et al. 2002; ElSayed et al. 2008; Dötterl et al. 2009). Each plant structure has, moreover, a specific odour profile (Proffit et al. 2007; Karlsson et al. 2009). In many cases, the insect locates its host plant through the volatile cues emitted from the exploited plant structure (Bruce et al. 2005; Bruce and Pickett 2011). There are numerous examples, wherein floral volatiles attract species-specific pollinators via advertisement of the availability of reward for the insect (Dobson and Bergström 2000; Grison-Pigé et al. 2002; Raguso 2008). Odours released from foliage attract herbivores to feed or oviposit (Finch and Collier 2000; Proffit et al. 2011), providing a reliable cue for an appropriate site 
to the insect. Foliage volatiles may furthermore have an indirect effect of attracting natural enemies of herbivores (Pichersky et al. 2002; Tamiru et al. 2011), similar to flower odours that attract florivores, which deter pollinators (Theis 2006; Adler et al. 2012) or predators (Raguso 2004). Indeed, the exploited plant structure is not always easily accessible or visible and the use of an indirect cue providing information on resource quality could represent a highly beneficial strategy for insects. In a few cases, there is a spatial separation between the site of the plant structure releasing the attractive odour and the structure used by the herbivore insect. For example, the scent of leaves, which advertise flower presence for the weevil Derelomus chamaeropsis Fabricius (Coleoptera: Curculionidae) (Dufaÿ et al. 2003) or the plant- and soil-emitted semiochemicals, enhances oviposition by the clover root weevil Sitona lepidus Gyllenhal (Coleoptera: Curculionidae) on the clover leaves (Johnson et al. 2006). In the case of phytophagous insects, whose life cycle includes a soilliving larval stage, the use of an informative cue of host suitability for offspring development by parental insects living above ground during host-plant selection could be a highly beneficial strategy. Shoot-mediated suitability of below-ground plant parts may guide adult insects for oviposition (Johnson et al. 2006).

The Guatemalan potato moth, Tecia solanivora Povolny (Lepidoptera: Gelechiidae), is a good example of a phytophagous insect with spatially separated larval and adult feeding sites. The only known hosts of $T$. solanivora are the potato species, Solanum tuberosum andigena, $S$. tuberosum tuberosum, S. chaucha, and S. phureja, all of which are tuberforming plants (Cifuentes and López-Ávila 2004; Cadena et al. 2005). It is not known where, or if, adults feed. The moth is distributed from Guatemala to Ecuador in Latin America and in the Canarias Islands, where it is a limiting pest on potato cultivation (Hilje 1994; Pollet et al. 2003). The number of Guatemalan potato moth trapped in potato field increases during the flowering stage of crop (Rodríguez et al. 1988; Barreto et al. 2003; Sánchez et al. 2005) and the main infestation occurs accordingly only after tuber formation and peak flowering (Torres et al. 1994; Barreto et al. 2003). In the field, females of $T$. solanivora deposit the majority of their eggs on the soil surface, close to the potato stem, so neither on the foliage nor on the flowers (López-Ávila and Barreto 2004; Karlsson et al. 2009). Likewise does the potato tuber moth Phthorimaea operculella (Zeller) (Lepidoptera: Gelechiidae) avoid ovipositing on the plants themselves but in the soil adjacent to host plants and not around non-hosts, which has taken as evidence that host-plant volatiles are involved in host-plant location (Traynier 1983).

So far, little is known about potato odour importance for $T$. solanivora location of mate and/or oviposition site. Interestingly, Bosa et al. (2011) reported that virgin females were more attracted to flower odour than to odours of the whole plant or to tubers, in an olfactometer test. As attraction to flowers among virgin female moths is generally associated with location of feeding sites and not of oviposition sites (Cunningham et al. 2006; Saveer et al. 2012), the role of potato flower odour in the host locating strategy of $T$. solanivora needs to be explored.

Potato emits volatile compounds that are species specific and others that indicate the quality and the phenological stage of the plants (Bolter et al. 1997; Agelopoulos et al. 2000; Karlsson et al. 2009, 2013). All potato plant structures, potato foliage, tubers, and flowers emit compounds, some of which are antennal active to $T$. solanivora (Karlsson et al. 2009). Semi-field trapping assays showed that the compound methyl phenylacetate (MPA) emitted from potato flowers in high amount and potato tubers in small quantities attracts $T$. solanivora. However, MPA in combination with a high concentration of 6-methyl-5hepten-2-one (sulcatone), a compound found in tubers, reduces the attraction (Bosa et al. 2011).

The aim of the present study was to characterize the cues used by $T$. solanivora to locate its host. We hypothesize that, because tuber formation and flowering peak occur simultaneously in potato plants, potato flower odour could guide females to find an oviposition site. To test this hypothesis, behaviour assays were conducted to observe response of $T$. solanivora to synthetic blends, identified from and representing different potato plant structures. The mating status influence in the behaviour was tested as well as the importance of individual compounds in the most attractive blend.

\section{Materials and methods}

\section{Experimental insects}

A laboratory colony of the Guatemalan potato moth $T$. solanivora, originating from the Colombian Corporation for Agricultural Research (Corpoica), was established. The colony was interbred regularly with wild Colombian moths and was reared on potato tubers in containment facilities at SLU, Sweden. Insects were maintained in $60 \pm 10 \% \mathrm{RH}$ and $18 \pm 2{ }^{\circ} \mathrm{C}$ under a photoperiod of L16:8D. Adults for electrophysical experiment were kept in Plexiglas cages $\left(33 \times 33 \times 33 \mathrm{~cm}^{3}\right)$ and fed with $10 \%$ honey solution, whereas adults for the olfactometer assays were fed only with water $24 \mathrm{~h}$ before experiments.

\section{Electroantennography}

Synthetic compounds (Table 1) were tested in a dose-response function with electroantennographic recording 
Table 1 Synthetic chemical compounds used for electroantennal- and behavioural assays

\begin{tabular}{|c|c|c|c|}
\hline Compound name & CAS-nr ${ }^{\mathrm{a}}$ & Brand & Purity $\%$ \\
\hline Benzaldehyde & $100-52-7$ & Fluka & 99.5 \\
\hline$\delta$-Elemene & $20307-84-0$ & $\mathrm{Gift}^{\mathrm{b}}$ & $>75$ \\
\hline$\delta$-Cadinene & $483-76-1$ & Florida chemical & 85.5 \\
\hline$\alpha$-Caryophyllene & $4586-22-5$ & Sigma Aldrich & $>85$ \\
\hline$\beta$-Caryophyllene & $87-44-5$ & Fluka & 98.5 \\
\hline$\alpha$-Copaene & $3856-25-5$ & Sigma Aldrich & $>90$ \\
\hline$\alpha$-Cubebene & $17699-14-8$ & $\mathrm{Gift}^{\mathrm{b}}$ & $>75$ \\
\hline Decanal & $112-31-2$ & Sigma Aldrich & 98 \\
\hline$(E, E)$ - $\alpha$-Farnesene & $502-61-4$ & Bedoukian & $>95$ \\
\hline (E)- $\beta$-Farnesene & $18794-84-8$ & Bedoukian & 90 \\
\hline Germacrene D & $23986-74-5$ & $\mathrm{Gift}^{\mathrm{b}}$ & $>75$ \\
\hline Methyl phenylacetate & $101-41-7$ & Sigma Aldrich & 99 \\
\hline$\beta$-Myrcene & $123-35-3$ & ICN Biomedicals & 90 \\
\hline Nonanal & $124-19-6$ & Fluka & 95 \\
\hline 3-Octanone & $106-68-3$ & Fluka & Purum \\
\hline 1-Octen-3-ol & $3391-86-4$ & Acros AG & 98 \\
\hline Phenylacetaldehyde & $122-78-1$ & Sigma Aldrich & 95 \\
\hline 2-Phenylethanol & $60-12-8$ & Merck-Schuchardt & 98 \\
\hline Sabinene & $3387-41-5$ & Fluka & 98.5 \\
\hline Sulcatone & $110-93-0$ & Sigma Aldrich & 99 \\
\hline Tetradecanal & $124-25-4$ & unknown & $>70$ \\
\hline
\end{tabular}

${ }^{a}$ CAS, Chemical Abstracts Service number

${ }^{\mathrm{b}}$ Gift from Prof. Anna-Karin Borg-Karlsson, KTH Stockholm, Sweden

technique (EAG) over four orders of magnitude: 0.01, 0.1, 1 and $10 \mu \mathrm{g}^{-1}$. The compounds were diluted in hexane (99.9\% Lichrosolve, Merck KGaA, Darmstadt, Germany). Identification and quantification of potato, Solanum tuberosum, var. Princess, odour were predominantly done in a previous study (Karlsson et al. 2009). Those analyses, besides combined gas chromatography and electroantennal detection (GC-EAD), revealed 17 compounds in potato headspace that are antennal active for $T$. solanivora. Additional collection from the same plant species and variety, tested with GC-EAD on females, showed that benzaldehyde, 1-octen-3-ol, 3-octanone, and 2-phenylethanol, are also antennal active. Thus, synthetic versions of these four compounds were here tested alongside the previously identified compounds. Female insects, aged 2-3-day post emergence and 12-24-h post mating were used for the assay. Unsexed pupae were left in a cage to allow adults to emerge and mate. For the first $30 \mathrm{~min}$ after the onset of the photophase, any copulating pairs were selected and gently transferred to a new case. Males and females were separated into different cages after a single complete mating event. Antennae were cut at the base and mounted with electroconductive gel (Cefar, Lund, Sweden) in a forked antenna holder (Syntech Equipment and Research, Kirchzarten, Germany) and continuously exposed to charcoal-filtered and humidified air $\left(1.51 \mathrm{~min}^{-1}\right)$. The odour stimuli were prepared by applying $10 \mu \mathrm{l}$ of each compound and at each dose on pieces of filter paper $(0.5 \times 2 \mathrm{~cm})$, inserted in a Pasteur pipette. A puffing device (Syntech stimulus controller CS-55) delivered a 0.5 -s long air puff with a flow of $1 \mathrm{ml} \mathrm{sek}^{-1}$ through the Pasteur pipette and into the humidified airstream passing over the antenna. Each antenna was exposed to a series of stimuli, within one concentration level, that were presented in random order, to avoid sphericity. The stimuli series always started and ended with blank, hexane, and female pheromone component (E)-3-dodecenyl acetate, [(E)-3-12:Ac) (Pherobank, Wageningen, The Netherlands $>99.6 \%$ ] (Nesbitt et al. 1985) as the reference, since this compound had shown reproducible EAG responses. Each stimulus was presented at least $1 \mathrm{~min}$ after the previous stimulus to avoid adaptation of the antenna. The maximum amplitude of the EAG responses was recorded and analysed with the EAG-adapted software (Syntech, EAGPro ver. 2.0). 


\section{Y-tube olfactometer assay}

A behavioural assay was set up to compare attraction to synthetic blends representing potato flower, foliage, and potato tuber, against control (hexane or potato tubers). Preference test between potato tubers and the most attractive blend was thereafter performed. Two-to-four-day-old males and females, both mated and virgin, were tested in olfactometer bioassays. Virgin adults were prepared by separating sexes at the pupal stage, using the location of the genital pore as a differentiation criterion (Rincón and López-Ávila 2004) and placing them thereafter in separate cages. Mated insects were tested 12-24-h post mating. Prior to each assay, moths were allowed to acclimatize for $12 \mathrm{~h}$, individually separated in glass tubes $(\varnothing 3 \mathrm{~cm} \times 12.5 \mathrm{~cm})$ in the bioassay room. Each moth was used only once and was not exposed to odour sources before the bioassay.

Synthetic blends for Y-tube olfactometer assays were made of synthetic compound prepared out of compounds that generated activity in the T. solanivora antenna and that also showed a significant positive correlation between dose and response in the EAG analysis. The selected compounds were mixed into three blends representing potato odours from flowers, foliage, and tubers, respectively (Table 2). The blends represented, in this way, potato odour, as we assume the moth would perceive the plant. The composition of the blends, amount and ratio, was based on compound emission from potato flowers, foliage, and tubers and adjusted to workable quantities (Karlsson et al. 2009). The synthetic compounds were diluted in hexane $(99.9 \%$ Lichrosolve, Merck KGaA, Darmstadt, Germany), which alone also constituted the control. A cotton wick was inserted in a Teflon tube ( $\varnothing 2 \mathrm{~mm}$ and $30 \mathrm{~mm}$ long), which was thereafter inserted in a 2-ml vial. The synthetic treatments and the control were dispensed into vials and released through the cotton wicks. Release rates of the treatments were set by the evaporation rate of the carrier solvent, hexane. During the assay, vials were placed separately in 1.5-1 glass chambers. One treatment consisted of tubers of potato, Solanum tuberosum var. Princess. One kilogram of tubers was placed inside the glass chamber. Each chamber was connected with Teflon tubes to one of the two 20-cm-long branches of the Y-tube shaped olfactometer that converged into a $20-\mathrm{cm}$ long common arm $(\varnothing 35 \mathrm{~mm})$. Moistened and charcoal-filtered air was pushed through each glass chamber, which delivered the control and the treatment at $0.2 \mathrm{~m} \mathrm{~s}^{-1}$ into the Y-tube olfactometer. Tests were conducted at scotophase condition with room temperature ranging between $17 \pm 2{ }^{\circ} \mathrm{C}$ and $\mathrm{RH} 70 \pm 5 \%$. A $1 \mathrm{~W}$ red-light LED lamp allowed for behavioural observation.

Moths were placed individually at the entrance of the common arm in the Y-tube. The moth was able to walk in the tubes and make minor flights. The position of the moth was recorded after $10 \mathrm{~min}$. A response was scored when the insects walked further than two-thirds into one of the test arms and remained in that arm until the end of the test period. No choice was noted if the moth remained in the common arm. The position, left and right arm, of the tested treatments was changed randomly and noted. During the time, the insects spent in the Y-tube their behaviour were observed and recorded. The olfactometer were rinsed with soap and ethanol after every five moth tested and burned in a $300{ }^{\circ} \mathrm{C}$ hot oven overnight $(8 \mathrm{~h})$. We observed and registered behaviours such as probing with the ovipositor, proboscis extension, and insect motion in the tube.

\section{Oviposition assay}

An assay was conducted to examine the effect of the most attractive blend on oviposition. One pair of 2-3-day-old male and female was first placed together in a $12.5-\mathrm{cm}$ long glass tubes $(\varnothing 30 \mathrm{~mm})$ in the beginning of the photophase. Pieces of fabric $(50 \times 50 \mathrm{~mm})$ were fastened with rubber bands over the openings of each end of the tubes. These pieces of fabric closed the tube and served in the same time as an oviposition substrate for the moth that does not lay eggs on very smooth surfaces as the glass. Mating pairs were selected and placed in a humidified airstream, $0.2 \mathrm{~m} \mathrm{~s}^{-1}$, with an addition of either the solvent, hexane, or the flower blend that were used in the Y-tube bioassays described above. The release rate of the solvent and thereby of the compounds was controlled as described in the olfactometer assay. The number of eggs laid on the fabric was counted in the beginning of the following scotophase. The oviposition per female was counted once and 100 females were tested per treatment.

\section{Statistical analyses}

Dose-dependent response in electroantennographical assays was calculated by first subtracting the amplitude of the EAG response of the solvent from the EAG response of each compound. This was followed by dividing the stimulus response by the mean of the responses to the reference $(0.1 \mu \mathrm{g}(E)-3-12: A c)$ applied before and after the test stimulus, achieving a relative response. The residuals of the variables were normally distributed for most responses $(P>0.05$ D'Agostino-Pearson normality test) and for those, repeated measures ANOVA were done, followed by Tukey's multiple comparison test, to analyse the response to the different doses. For responses that were not normally distributed, Friedmans nonparametric test and Dunn's post test were used (Prism 5.0a, Graphpad Software).

To determine moth attraction in the olfactometer assays, data from each compound blend were arranged in a $2 \times 2$ contingency table. Using Fishers exact test, we compared 
Table 2 Foliage, tuber, and flower blend composition in T. solanivora behavioural assays, representing measured potato plant emission [ng plant ${ }^{-1} \mathrm{~h}^{-1}$ ]

\begin{tabular}{lrlllc}
\hline Foliage blend & ng & Tuber blend & ng & Flower blend & ng \\
\hline$\beta$-Caryophyllene & 2000 & Decanal & 80 & Methyl phenylacetate (MPA) & 8000 \\
$\beta$-Myrcene & 400 & 3-Octanone & 80 & Phenylacetaldehyde (PAA) \\
$(E, E)$ - $\alpha$-Farnesene & 400 & 1-Octen-3-ol & 80 & 2-Phenylethanol (PE) \\
$(E)-\beta$-Farnesene & 200 & Nonanal & 80 & MPA & 120
\end{tabular}

Phenylacetaldehyde

2-Phenylethanol
40

40

40
Methyl phenylacetate

Benzaldehyde<smiles>COC(=O)Cc1ccccc1</smiles>

40

$40 \quad P A A$<smiles>O=CCc1ccccc1</smiles>

Nonanal

Sulcatone
Phenylacetaldehyde

20

20

$P E$

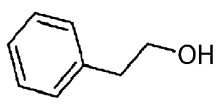

the proportion of moths that chose the right olfactometer arm or the left when the tested odour was on the left vs. on the right (excluding the 'non-responders). The null hypothesis, here, was that if the tested odour had no effect on moth behaviour (e.g., attraction or repulsion); the distribution of the moth between the left and right arms of the olfactometer should be the same when the tested odour is offered on the left and on the right arm of the olfactometer. The additional behaviours observed performed by the insect in the olfactometer were analysed in a $2 \times 2$ contingency test comparing the number insects with additional behaviours, with responding insects in each group (sex and mating status).

The effect of the floral blend on the number of eggs laid per female was tested with a generalized linear mixed model (glmm) with day as a random factor, under Poisson distribution using the package lme4 (Bates et al. 2014) in $\mathrm{R}$ (R Core Team 2014).

\section{Results}

\section{Electroantennography dose-dependent response}

Out of the 21 compounds tested, 13 showed a significant positive dose-dependent response (Table 3). The compounds benzaldehyde, $\beta$-caryophyllene, decanal, $(E, E)$ - $\alpha$-farnesene, $(E)$ - $\beta$-farnesene, methyl phenylacetate, $\beta$-myrcene, nonanal, 3-octanone, 1-octen-3-ol, phenylacetaldehyde, 2-phenylethanol, and sulcatone significantly increased the response with an increased dose, while several sesquiterpenes, e.g., $\alpha$-caryophyllene, $\delta$-elemene, and germacrene D, did not increased the EAG response with increased dose (Fig. 1; Table 3). Response to tetradecanal was low, hindering further analysis and usage of the compound. The 13 compounds, which elicited an enhanced response, caused by the quantity of the compounds on the filter paper, were selected to prepare synthetic blends for further bioassays.

\section{Olfactometer assays}

In the first set of dual-choice bioassays, three synthetic potato blends (Table 2) were tested against a control of hexane alone. Whereas no significant difference in moth attraction behaviour was observed between tuber blend and control for virgin males and mated females, mated males and virgin female moths significantly avoided the tuber blend (Fig. 2a). In this dual choice, almost $70 \%$ of mated males and virgin females choose the control test tube. Neither male nor female moth significantly preferred foliage blend to control (Fig. 2b). Tecia solanivora males and 
Table 3 Dose effect of the synthetic chemical compounds on the EAG response of Tecia solanivora females

\begin{tabular}{lrll}
\hline Compound name & $N$ & $F$ value $^{\mathrm{a}}$ & $P$ value \\
\hline Benzaldehyde & 10 & 9.192 & 0.0002 \\
$\delta$-Elemene & 6 & 1.412 & 0.2781 \\
$\delta$-Cadinene & 10 & $\mathrm{~b}$ & 0.5296 \\
$\alpha$-Caryophyllene & 10 & 0.211 & 0.0894 \\
$\beta$-Caryophyllene & 9 & 9.817 & 0.0002 \\
$\alpha$-Copaene & 11 & 2.007 & 0.1341 \\
$\alpha$-Cubebene & 9 & $\mathrm{c}$ & 0.4868 \\
Decanal & 16 & 11.57 & $<0.001$ \\
(E,E)- $\alpha$-Farnesene & 10 & 9.908 & 0.0001 \\
(E)- $\beta$-Farnesene & 10 & 7.541 & 0.0008 \\
Germacrene D & 10 & 1.984 & 0.1401 \\
Methyl phenylacetate & 15 & $\mathrm{~b}$ & $<0.001$ \\
$\beta$-Myrcene & 10 & 7.951 & 0.0006 \\
Nonanal & 11 & $\mathrm{~b}$ & $<0.001$ \\
3-Octanone & 8 & $\mathrm{~b}$ & 0.0079 \\
1-Octen-3-ol & 11 & 15.07 & $<0.001$ \\
Phenylacetaldehyde & 10 & 6.228 & 0.0024 \\
2-Phenylethanol & 10 & 5.576 & 0.0041 \\
Sabinene & 10 & 0.822 & 0.4934 \\
Sulcatone & 11 & 14.56 & $<0.001$ \\
Tetradecanal & 2 & $\mathrm{n} . \mathrm{a}$. & $\mathrm{n} . \mathrm{a}$. \\
\hline Repeated & & &
\end{tabular}

${ }^{a}$ Repeated measures one-way ANOVA

b Non-parametric Friedman's test

c Paired $t$ test

females, both mated and virgin, were significantly attracted by the synthetic floral blend. Approximately $70 \%$ of the insects choose the arm of the olfactometer with the flower blend (Fig. 2c). In the dual-choice assay between potato tubers and the control, no significant directional trends for any of the tested groups were found (Fig. 2d). In the choice between flower blend and potato tubers, virgin and mated males were significantly more attracted to the floral blend than to the potato tubers, while females did not significantly chose between tubers or flower blend (Fig. 2e).

Analysis of observed moth behaviours in the olfactometer revealed that mated females displayed probing behaviour with the ovipositor more than the virgins in the experiments with potato tubers $\left(\chi^{2}=9.515, d f=1\right.$, $P=0.002$ ), while in the other experiment, there was no difference in how often the ovipositor was extended (Table 4). Proboscis extension was only observed in about $1 \%$ of the tested insects.

\section{Oviposition}

The number of eggs laid per female differed between treatment with the synthetic three-component flower blend
Fig. 1 EAG dose response curves for Tecia solanivora females to synthetic plant volatiles. EAG amplitudes are control-adjusted and presented as relative response to the standard $0.1 \mu \mathrm{g}(E)-3-12$ :Ac (Tecia solanivora pheromone). Doses tested were $0.01,0.1,1$, and $10 \mu \mathrm{g} \mu \mathrm{l}^{-1}$. ns not significant, $n t$ not tested

and the control $\left(\mathrm{glmm}, \chi^{2}=287.21, d f=1 ; P<0.001\right)$ and was higher in the presence of the flower blend $[35.7 \pm 2.9$ (mean $\pm \mathrm{SE}), N=110]$ than in the control $(23.7 \pm 2.6, N=105)$.

\section{Discussion}

By combining electrophysiological recordings and behavioural assays, we characterised olfactory cues used by the Guatemalan potato moth to locate its host, potato. An attractive odour cue is emitted by potato flowers and corresponds to a blend of three structurally similar compounds, methyl phenylacetate, phenylacetaldehyde, and 2-phenylethanol. Oviposition was significantly higher when moths were held in an airstream of the three-component flower blend, than in the control. This result indicates that mated females distinguish oviposition sites by a compound blend emitted specifically by potato flowers and that flower odour is a cue for a preferred oviposition site. The divergence between the plant structure that is exploited by the insect (potato tubers) and the plant part with an attractive odour emission (potato flowers) is one of the very few examples, where spatially separated plant structures emit cues representing the presence of a suitable host in the vicinity (Dufaÿ et al. 2003; Johnson et al. 2006; Kehl et al. 2010).

Potato growth can be divided into phenological phases such as sprouts emergence and root growth followed by leaf development and tuberization. The development of tubers coincides with the flowering of the plant (Rodríguez-Falcón et al. 2006). Since $T$. solanivora larvae feed exclusively on tubers, this implies that the most suitable stage for the larvae is correlated with the flowering of the plant. Our results corroborate the "preference-performance" hypothesis, or "mother knows the best", first proposed by Jaenike (1978), stipulating that females are usually attracted to plant species, plant structure, and/or phenological stage that offer a positive influence on the progeny performance (Masante-Roca et al. 2007; Proffit et al. 2007; Gripenberg et al. 2010). The adult lays eggs in the soil near the base of the plant and it is the first instar larvae that locate the potato tuber in the soil by geotaxis and no chemical cues influence its orientation (Camargo Gil et al. 2010). For larvae of $T$. solanivora, like most Lepidoptera larvae, survival depends of fast location of a 

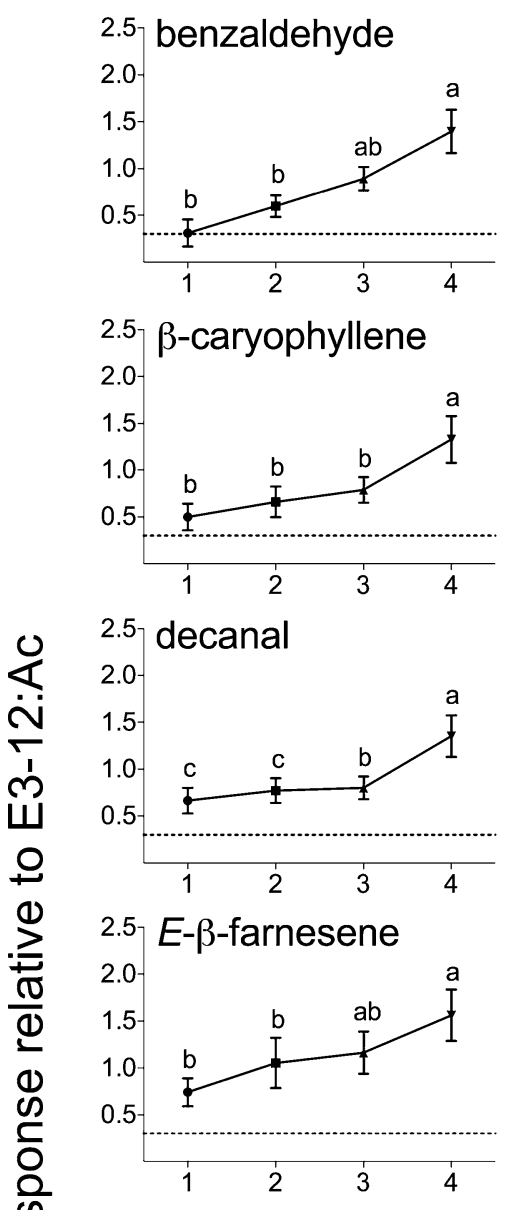

क
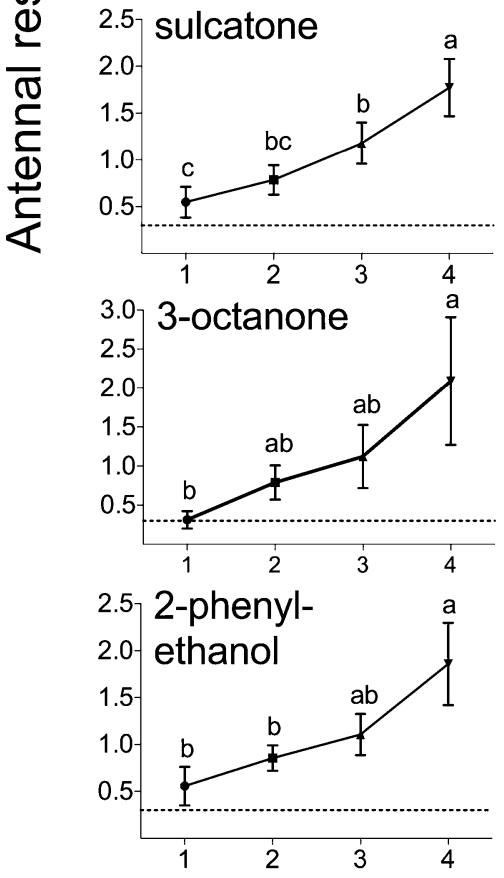
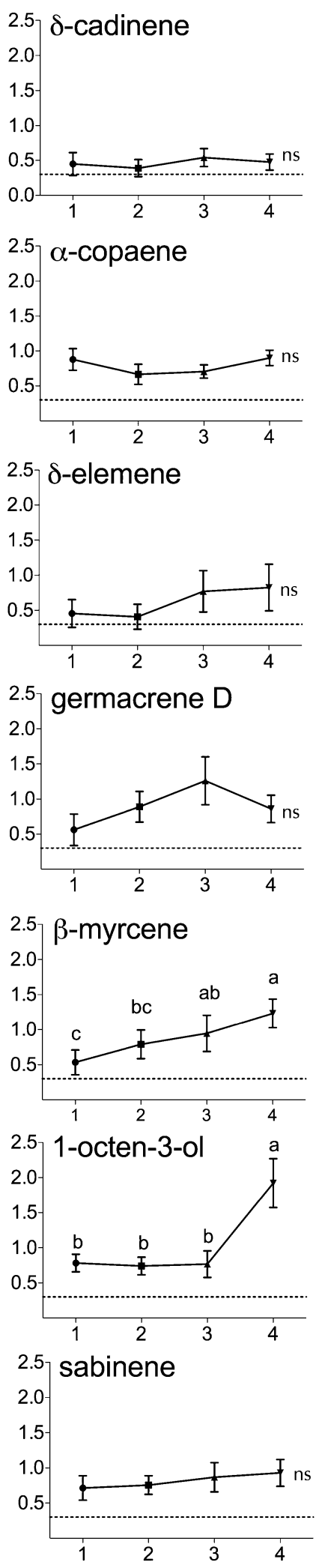

Dose [log ng]
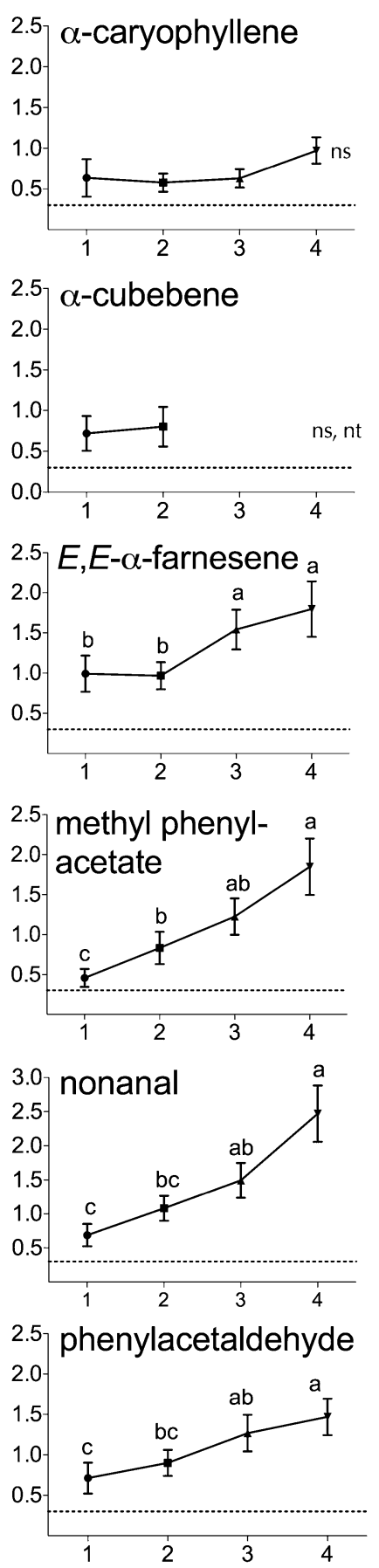
food source and onset of feeding. Yet, neonates are exposed on the soil and their vulnerability is dependent on the oviposition choice of the adult.

Most electroantennal active compounds consistently showed a dose-dependent antennal detection by individual moths. Blends created based on these compounds might be considered the odour of potato as $T$. solanivora perceive the plant, since the blends do not contain the full bouquet of volatile compounds emitted by potato. The synthetic blends representing foliage and tuber odour were not attractive in our study. In fact, synthetic tuber blend was even significantly less preferred than the control. Our
A
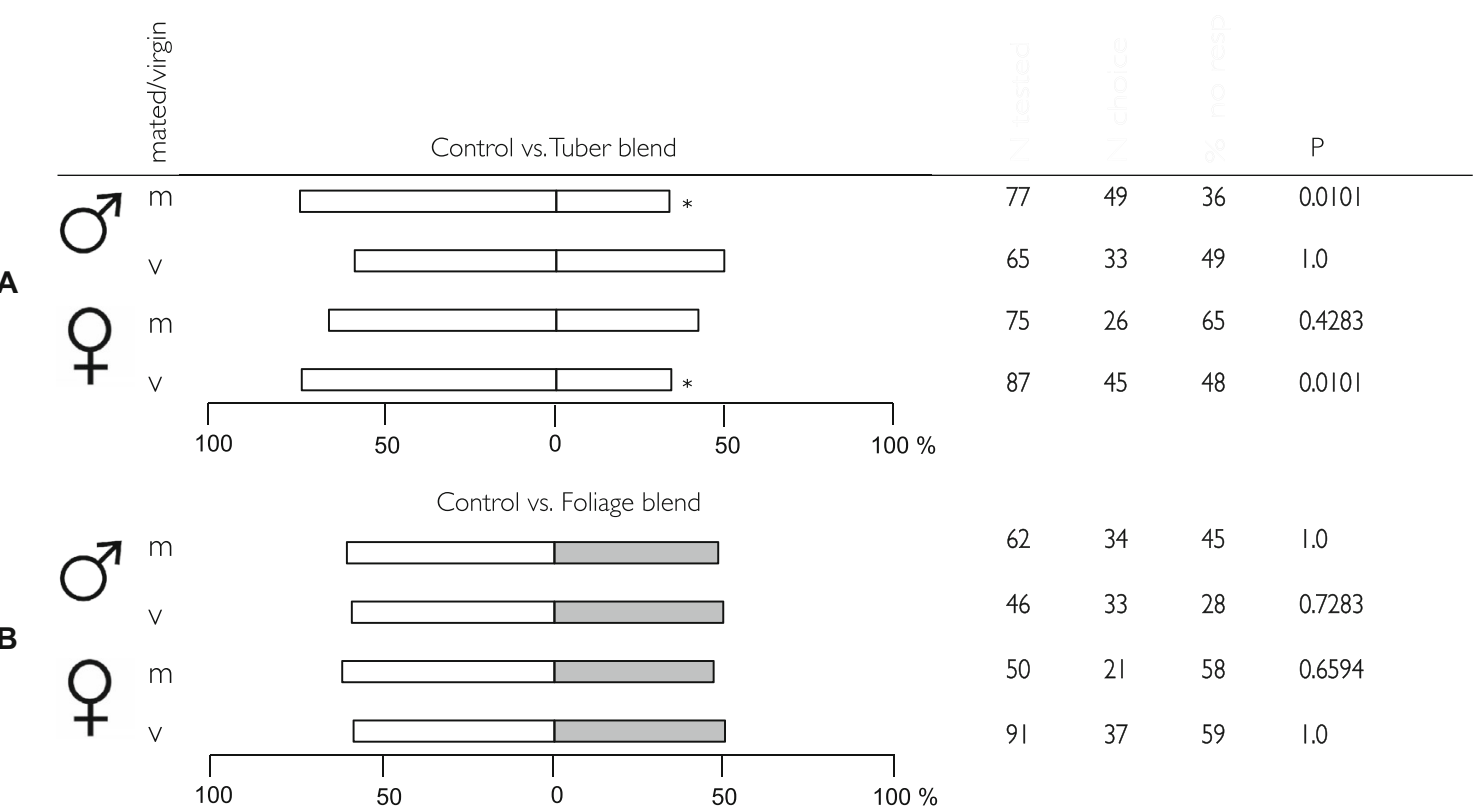

Control vs. Flower blend<smiles>COC(=O)c1ccccc1</smiles>

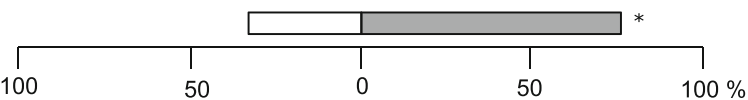

Control vs. Tubers

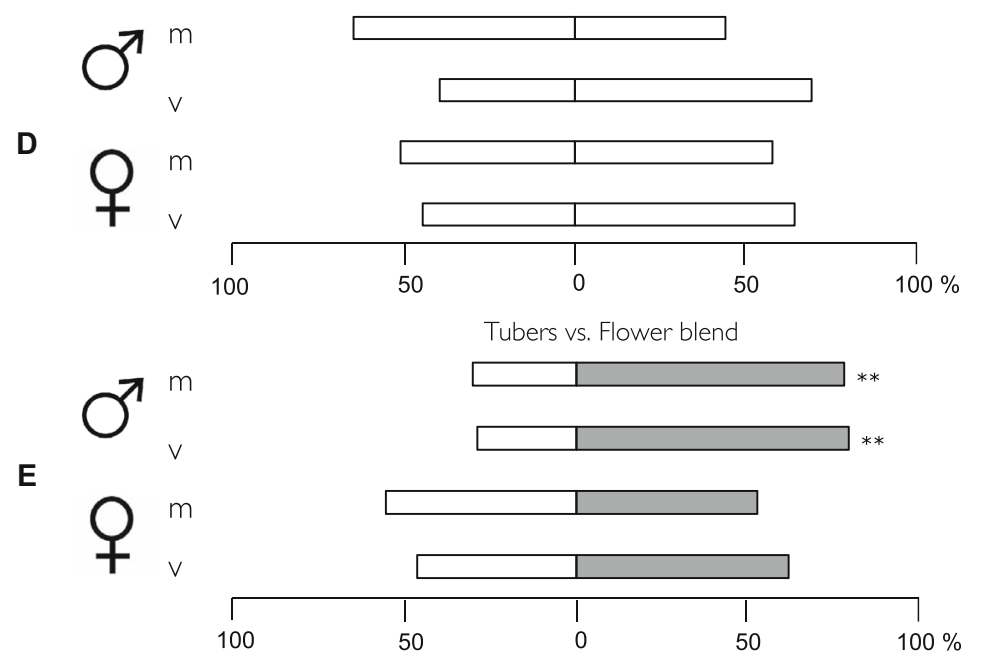

$\begin{array}{llll}62 & 34 & 45 & 1.0\end{array}$

$\begin{array}{llll}46 & 33 & 28 & 0.7283\end{array}$

$\begin{array}{llll}50 & 21 & 58 & 0.6594\end{array}$

$\begin{array}{llll}91 & 37 & 59 & 1.0\end{array}$

$\begin{array}{llll}106 & 64 & 40 & 0.0026 \\ 55 & 30 & 45 & 0.0011 \\ 108 & 49 & 55 & 0.0090 \\ 47 & 33 & 30 & 0.0377\end{array}$

$\begin{array}{llll}98 & 42 & 57 & 0.2077\end{array}$

$\begin{array}{llll}66 & 44 & 33 & 0.3129\end{array}$

$\begin{array}{llll}77 & 32 & 58 & 1.0\end{array}$

$\begin{array}{llll}90 & 44 & 51 & 0.2457\end{array}$

$\begin{array}{llll}56 & 43 & 23 & 0.0058\end{array}$

$\begin{array}{llll}32 & 30 & 6 & 0.0067\end{array}$

$\begin{array}{llll}43 & 35 & 19 & 0.7241\end{array}$ $\begin{array}{llll}63 & 39 & 38 & 0.7526\end{array}$

Fig. 2 Response of male and female, virgin and mated Tecia solanivora, in Y-tube experiments when presented with odour blends (Table 2) vs control (a-d). a Tuber blend; b foliage blend; c flower blend; d tuber; and e tuber vs flower blend 
Table 4 Tecia solanivora ovipositor extension during olfactometer assays in different treatment combinations

\begin{tabular}{lcll}
\hline Treatment combination & Virgin $(\%)$ & Mated $(\%)$ & $P^{\mathrm{a}}$ \\
\hline Tuber blend vs control & 7 & 12 & 0.413 \\
Foliage blend vs control & 7 & 16 & 0.176 \\
Flower blend vs control & 10 & 20 & 0.19 \\
Tubers vs flower blend & 0 & 11 & 0.006 \\
Tubers vs control & 2 & 31 & $<0.001$ \\
${ }^{\mathrm{a}} \chi^{2}$ test & & &
\end{tabular}

results for the foliage blend concur partly with earlier work that showed that $T$. solanivora selection of odour source in a 4-arm olfactometer did not differ between whole potato plant and the control, while odour of flower was selected the most (Bosa et al. 2011). Composition of the tuber blend, causing a discrepancy between behavioural responses to tuber odour, might imply that the blend was not completely representative of tuber odour, for the moth. An incorrect proportion of the compounds might have caused the avoidance observed here of the synthetic blend. An incomplete headspace collection, identification, and/or calculation of the release quantity might also account for the divergence in behavioural response between tubers and tuber blend.

Host-plant odours generally elicit attraction behaviour in Lepidoptera species while locating feeding sites (Browne 1993; Dobson and Bergström 2000), oviposition sites (Grant et al. 2007; Anfora et al. 2009), or mating encounter sites (Tasin et al. 2005). Currently, adult feeding behaviour of $T$. solanivora in the field is unknown, but it is unlikely that potato elicits attraction to feed. The Guatemalan potato moth has not been reported visiting flowers. In addition, potato flowers are nectarless and pollen is the sole reward for visiting insects. Most flowers in the genus Solanum are showy and sweet-scented (Buchmann and Cane 1989) and exclusively buzz-pollinated by bumble bees (Anderson et al. 1988) or by specialized solitary bee species from the Apidae, Colletidae, and Halictidae families that vibrate flowers to extract the pollen from the merged anther cones (Kessler et al. 2011). Hence, the attraction of T. solanivora to potato flower blend is probably an indicator of a suitable phenological stage, i.e., the formation of tubers, rather than a food source for the moth.

The three-component flower blend, comprising of methyl phenylacetate, phenylacetaldehyde, and 2-phenylethanol, was attractive to both females and males, virgin and mated. Our results suggest that these three biosynthetically closely related substances are important for the adult moth host finding (see Table 2 for structural formulae). Potato flowers close during the night, potentially reducing odour emission. When the sun rises, the flowers open again, concurrently with the onset of female calling. At sunrise, or during the onset of an artificial photophase, females start to call. This last for approximately $30 \mathrm{~min}$. Tecia solanivora males and females are penumbras and are most active and fly around between 5 and $8 \mathrm{a} . \mathrm{m}$. and to a lesser degree between 6 and 7 p.m. (Barreto et al. 2003). It is known that a combination of pheromone components and plant compounds, such as floral scent, can enhance male attraction in phytophagous insect species (Reddy and Guerrero 2004). The presence of host plants can also increase pheromone production and emission, and elicit earlier onset and prolonged calling behaviour (Ochieng et al. 2002; Srinivasan et al. 2003; Sadek and Anderson 2007). For virgin adults, flower compound might influence the mate-searching behaviour. Our results are comparable to those of previous studies on the influence of host plants on mate-searching of Heliconius charithonia L. (Lepidoptera: Nyphalidae) (Estrada and Gilbert 2010) and with female-calling behaviour in Helicoverpa armigera Hubner (Lepidoptera: Noctuidae) (Xiao et al. 2002). It is known that if mating occurs next to the host plant and if both sexes search the host place prior to mating, the probability to encounter a conspecific is increased, especially for monophagous insects (Browne 1993; Wickman and Rutowski 1999). We hypothesize that the same flower odour acts as an odour cue for virgin insects, attracting them to the potato plant in the morning, which indirectly enhances the probability of encounter.

Mated females of many phytophagous moth species have an increased behavioural responsiveness, than virgin females, to host-plant odour (Tingle et al. 1989; Odendaal and Rausher 1990; Masante-Roca et al. 2007; Saveer et al. 2012). For example, mated females of $P$. operculella and Tuta absoluta Meyrick (Lepidoptera: Gelechiidae) are more attracted to their respective host plants, potato and tomato, than virgin females (Arab et al. 2007; Proffit et al. 2011). We observed, on the contrary, that the general behavioural responsiveness for $T$. solanivora tended to be higher by virgin females than by mated females. Complementary bioassays are required to test this difference as well as differences between treatments. Our observed higher responsiveness by virgin females might as well indicate an adaptation to minimize the cost of remaining unmated for a long time (Bergman et al. 2011). Because mating occurs next to the host plant, the already-mated females have less need to search for suitable host and mating (Milonas et al. 2011). Searching might therefore decrease just after mating, and the insects stay close to the host to oviposit in the soil nearby. Tecia solanivora oviposition begins during the first scotophase after mating and continues for several subsequent days (Karlsson, pers. observ.; (Torres et al. 1994). In our olfactometer assay, mated females extended their ovipositor significantly more 
often than the virgin females, which indicates that the mated females were ready to oviposit during the time of the bioassay. Ovipositor extension and dragging of ovipositor over the surface to evaluate the suitability of the site is related to the assessment process of the host-plant surface as mechano- and chemosensory receptors are found in the ovipositor in Lepidoptera (Renwick and Chew 1994). For $T$. solanivora as well as $P$. operculella, the surface structure is important for oviposition and they will extremely rarely oviposit on a smooth surface like glass, but prefer a rough dry surface, such as soil or substrates that provide depressions (Fenemore 1988).

Our results show that both sexes of adult $T$. solanivora are attracted to their host plant by similar bouquet of compounds emitted by flowers. We conclude that mating close to the potato plant reinforces the chance of oviposition in/on/around the same plant, explaining the mated female attraction to flower odour, in search for an oviposition site. A possible explanation of the attraction by $T$. solanivora males is that potato flower odour can act in combination with the female sex pheromone, emitted at sunrise.

This study gives an interesting example of the complexity of host-plant selection strategies in phytophagous insects. Emission of some volatile compounds from potato flowers is ensuring the attraction of adults of both sexes to the suitable stage of the host plant for larval development. Females' absence of behavioural discrimination between the odour of the structure emitting the attractive cues, i.e., flower, and the odour of the actual exploited structure, i.e., the tuber, indicates that several odour cues might be involved in host-plant selection. Similar to Theis (2006) and Kehl et al. (2010), we show that flower scents are not only important cues for chemical communication between plants and their pollinators, but can also attract phytophagous insects even if they or their offspring do not feed from these organs. Oviposition behaviour of $T$. solanivora can be compared with the tomato fruit fly Neoceratitis cyanescens (Diptera: Tephritidae), which does not oviposit on flowers or fruit but are attracted to these organs (Brévault and Quilici 2010). The significant attractiveness of the flower blend in the olfactometer, as well as weak luring capacity by the flower blend in the field (Karlsson 2011), suggests that $T$. solanivora uses odour for long-range attraction, but that it may not be sufficient to elicit landing or acceptance on flowers, tubers not foliage in the short range. Future experiments with combination of volatile and visual cues from soil, potato tubers, and flowers, together with combination of flower compounds and pheromones may enhance our understanding of the intriguing host-plant selection behaviour of the Guatemalan potato moth.
Acknowledgements We would like to thank the Swedish International Development Cooperation Agency, SIDA, who financially supported M.F.K. through the project SWE-2006-435 during the study. We are also grateful to Bonaventure Omondi Aman for valuable comments on a previous version of the manuscript.

\section{Compliance with ethical standards}

Conflict of interest The authors declare that they have no conflict of interest.

Open Access This article is distributed under the terms of the Creative Commons Attribution 4.0 International License (http:// creativecommons.org/licenses/by/4.0/), which permits unrestricted use, distribution, and reproduction in any medium, provided you give appropriate credit to the original author(s) and the source, provide a link to the Creative Commons license, and indicate if changes were made.

\section{References}

Adler LS, Karban R, Strauss SY (2012) Direct and indirect effects of alkaloids on plant fitness via herbivory and pollination. Ecology 82:2032-2044

Agelopoulos NG, Chamberlain K, Pickett JA (2000) Factors affecting volatile emission of intact potato plants, Solanum tuberosum: variability of quantities and stability of ratios. J Chem Ecol 26:497-511. doi:10.1023/A:1005473825335

Anderson GJ, Symon D, Flowers S (1988) Insect foragers on Solanum flowers in Australia. Ann Mo Bot Gard 75:842-852

Anfora G, Tasin M, De Cristofaro A et al (2009) Synthetic grape volatiles attract mated Lobesia botrana females in laboratory and field bioassays. J Chem Ecol 35:1054-1062. doi:10.1007/ s10886-009-9686-5

Arab A, Trigo JR, Lourenção AL et al (2007) Differential attractiveness of potato tuber volatiles to Phthorimaea operculella (Gelechiidae) and the predator Orius insidiosus (Anthocoridae). J Chem Ecol 33:1845-1855. doi:10.1007/s10886-007-9358-2

Barreto N, Espitia E, Galindo R et al (2003) Estudios de fluctuación de poblaciones la polilla guatemalteca de la papa Tecia solanivora (Lepidóptera: Gelechiidae) en tres intervalos de altitud en Cundinamarca y Boyacá. In: Centro virtual de investigación de la cadena agroalimentaria de la papa CEVIPAPA II Taller Nacional sobre Tecia solanivora, Presente y futuro de la investigación sobre polilla guatemalteca, pp 188-190

Bates D, Maechler M, Bolker B, Walker S (2014) lme4: linear mixedeffects models using Eigen and S4. R Packag Version 1:1-7

Bergman M, Gotthard K, Wiklund C (2011) Mate acquisition by females in a butterfly: the effects of mating status and age on female mate-locating behaviour. Anim Behav 81:225-229. doi:10.1016/j.anbehav.2010.10.009

Bolter CJ, Dicke M, van Loon JJA et al (1997) Attraction of Colorado potato beetles to herbivore-damaged plants during herbivory and after its termination. J Chem Ecol 23:1003-1023. doi:10.1023/B: JOEC.0000006385.70652.5e

Bosa CFO, Karlsson MF, Cotes Prado AM, Witzgall P (2011) Respuesta de Tecia solanivora (Lepidoptera: Gelechiidae) a compuestos volátiles de papa, Solanum tuberosum. Rev Colomb Entomol 37:1-7

Brévault T, Quilici S (2010) Interaction between visual and olfactory cues during host finding in the tomato fruit fly Neoceratitis cyanescens. J Chem Ecol 36:249-259. doi:10.1007/s10886-010-9766-6 
Browne LB (1993) Physiologically induced changes in resourceoriented behaviour. Annu Rev Entomol 38:1-25

Bruce TJA, Pickett JA (2011) Perception of plant volatile blends by herbivorous insects-finding the right mix. Phytochemistry 72:1605-1611. doi:10.1016/j.phytochem.2011.04.011

Bruce TJA, Wadhams LJ, Woodcock CM (2005) Insect host location: a volatile situation. Trends Plant Sci 10:269-274. doi:10.1016/j. tplants.2005.04.003

Buchmann SL, Cane JH (1989) Bees assess pollen returns while sonicating Solanum flowers. Oecologia 81:289-294. doi:10. 1007/BF00377073

Cadena M, Naranjo A, Nústez CE (2005) Evaluating the response of 60 Solanum phureja (Juz. et Buk.) genotypes to attacks by the Guatemalan moth (Tecia solanivora Povolny). Agron Colomb 23:112-116

Camargo Gil C, Rincón Rueda DF, Valencia EP (2010) Localización de hospedero por larvas neonatas de Tecia solanivora (Lepidoptera: Gelechiidae). Corpoica Cienc Tecnol Agropecu 11:5-10

Cifuentes G, López-Ávila A (2004) Búsqueda de resistencia genética en la colección central colombiana a la polilla guatemalteca de la papa. In: XXXI Congreso de la Sociedad Colombiana de Entomología, Bogotá, pp 12

Cunningham JP, Moore CJ, Zalucki MP, Cribb BW (2006) Insect odour perception: recognition of odour components by flower foraging moths. Proc Biol Sci 273:2035-2040. doi:10.1098/rspb. 2006.3559

Dobson H, Bergström G (2000) The ecology and evolution of pollen odors. Plant Syst Evol 222:63-87

Dötterl S, Jürgens A, Wolfe LM, Biere A (2009) Disease status and population origin effects on floral scent: potential consequences for oviposition and fruit predation in a complex interaction between a plant, fungus, and noctuid moth. J Chem Ecol 35:307-319

Dufaÿ M, Hossaert-McKey M, Anstett MC (2003) When leaves act like flowers: how dwarf palms attract their pollinators. Ecol Lett 6:28-34

El-Sayed AM, Byers JA, Manning LM et al (2008) Floral scent of Canada thistle and its potential as a generic insect attractant. J Econ Entomol 101:720-727

Estrada C, Gilbert LE (2010) Host plants and immatures as matesearching cues in Heliconius butterflies. Anim Behav 80:231-239. doi:10.1016/j.anbehav.2010.04.023

Fenemore P (1988) Host-plant location and selection by adult potato moth, Phthorimaea operculella (Lepidoptera: Gelechiidae): a review. J Insect Physiol 34:175-177

Finch S, Collier RH (2000) Host-plant selection by insects-a theory based on "appropriate/inappropriate landings" by pest insects of cruciferous plants. Entomol Exp Appl 96:91-102. doi:10.1023/ A: 1004058518179

Grant GG, Guo J, MacDonald L, Coppens MD (2007) Oviposition response of spruce budworm (Lepidoptera: Tortricidae) to host terpenes and green-leaf volatiles. Can Entomol 139:564-575. doi:10.4039/n06-079

Gripenberg S, Mayhew PJ, Parnell M, Roslin T (2010) A metaanalysis of preference-performance relationships in phytophagous insects. Ecol Lett 13:383-393. doi:10.1111/j.14610248.2009.01433.x

Grison-Pigé L, Bessière J-M, Hossaert-McKey M (2002) Specific attraction of fig-pollinating wasps: role of volatile compounds released by tropical figs. J Chem Ecol 28:283-295

Hilje L (1994) Characterizatión del daño de las polillas de la papa, Tecia solanivora y Phthorimaea operculella (Lepidoptera: Gelechiidae), en Cartago, Costa Rica. Manejo Integr Plagas 31:43-46
Jaenike J (1978) On optimal oviposition behavior in phytophagous insects. Theor Popul Biol 14:350-356

Jhumur US, Dötterl S, Jürgens A (2006) Naive and conditioned responses of Culex pipiens pipiens biotype molestus (Diptera: Culicidae) to flower odors. J Med Entomol 43:1164-1170

Johnson SN, Birch ANE, Gregory PJ, Murray PJ (2006) The "mother knows best" principle: should soil insects be included in the preference-performance debate? Ecol Entomol 31:395-401. doi:10.1111/j.1365-2311.2006.00776.x

Karlsson MF (2011) Role of semiochemicals in host finding, oviposition and sexual communication in Guatemalan Potato Moth Tecia solanivora. PhD thesis, Swedish University of Agricultural Sciences, ISBN: 9789157675996

Karlsson MF, Birgersson G, Cotes Prado AM et al (2009) Plant odor analysis of potato: response of guatemalan moth to above- and belowground potato volatiles. J Agric Food Chem 57:5903-5909. doi:10.1021/jf803730h

Karlsson MF, Birgersson G, Witzgall P et al (2013) Guatemalan potato moth Tecia solanivora distinguish odour profiles from qualitatively different potatoes Solanum tuberosum L. Phytochemistry 85:72-81. doi:10.1016/j.phytochem.2012.09.015

Kehl A, Dötterl S, Aas G, Rambold G (2010) Is flower scent influencing host plant selection of leaf-galling sawflies (Hymenoptera, Tenthredinidae) on willows? Chemoecology 20:215-221. doi:10.1007/s00049-010-0050-6

Kessler A, Halitschke R, Poveda K (2011) Herbivory-mediated pollinator limitation: negative impacts of induced volatiles on plant-pollinator interactions. Ecology 92:1769-1780

López-Ávila A, Barreto N (2004) Generación de componentes tecnológicos para el manejo integrado de la polilla guatemalteca de la papa Tecia solanivora (Povolny) con base en el conocimiento de la biología, comportamiento y dinámica de la población de la plaga. In: Corporación Colombiana de Investigación Agropecuaria (CORPOICA), National integrated pest management program, Technical report, pp 159

Masante-Roca I, Anton S, Delbac L et al (2007) Attraction of the grapevine moth to host and non-host plant parts in the wind tunnel: effects of plant phenology, sex, and mating status. Entomol Exp Appl 122:239-245. doi:10.1111/j.1570-7458.2006. 00510.x

Milonas PG, Farrell SL, Andow DA (2011) Experienced males have higher mating success than virgin males despite fitness costs to females. Behav Ecol Sociobiol 65:1249-1256. doi:10.1007/ s00265-011-1138-x

Nesbitt BF, Beevor PS, Cork A et al (1985) Identification of components of the female sex pheromone of the potato tuber moth, Scrobipalpopsis solanivora. Entomol Exp Appl 38:81-85

Ochieng SA, Park KC, Baker TC (2002) Host plant volatiles synergize responses of sex pheromone-specific olfactory receptor neurons in male Helicoverpa zea. J Comp Physiol A Neuroethol Sens Neural Behav Physiol 188:325-333. doi:10. 1007/s00359-002-0308-8

Odendaal FJ, Rausher MD (1990) Egg load influences search intensity, host selectivity, and clutch size in Battus philenor butterflies. J Insect Behav 3:183-193. doi:10.1007/BF01417911

Pichersky E, Jonathan G, Gershenzon J (2002) The formation and function of plant volatiles: perfumes for pollinator attraction and defense. Curr Opin Plant Biol 5:237-243

Pollet A, Barragan AR, Zeddam JL, Lery X (2003) Tecia solanivora, a serious biological invasion of potato cultures in South America. Int Pest Control 45:139-144

Proffit M, Schatz B, Borges RM, Hossaert-McKey M (2007) Chemical mediation and niche partitioning in non-pollinating fig-wasp communities. J Anim Ecol 76:296-303. doi:10.1111/j. 1365-2656.2007.01213.x 
Proffit M, Birgersson G, Bengtsson M et al (2011) Attraction and oviposition of Tuta absoluta females in response to tomato leaf volatiles. J Chem Ecol 37:565-574. doi:10.1007/s10886-0119961-0

R Core Team (2014) R: a language and environment for statistical computing. R Foundation for Statistical Computing, Vienna, ISBN 3-900051-07-0. http://www.R-project.org

Raguso RA (2004) Why are some floral nectars scented? Ecology 85:1486-1494

Raguso RA (2008) Wake up and smell the roses: the ecology and evolution of floral scent. Annu Rev Ecol Evol Syst 39:549-569. doi:10.1146/annurev.ecolsys.38.091206.095601

Reddy GVP, Guerrero A (2004) Interactions of insect pheromones and plant semiochemicals. Trends Plant Sci 9:253-261. doi:10. 1016/j.tplants.2004.03.009

Renwick JAA, Chew F (1994) Oviposition behavior in Lepidoptera. Annu Rev Entomol 39:377-400

Rincón DF, López-Ávila A (2004) Dimorfismo sexual en pupas de Tecia solanivora (Povolny) (Lepidoptera: Gelechiidae). La Rev Corpoica-Cienc y Tecnol Agropecu 5:41-42

Rodríguez V, Murillo R, Lépiz C (1988) Fluctuación de las capturas de las polillas de las papas Scrobipalpopsis solanivora Povolny y Phthorimaea operculella Zeller (Lepidoptera, Gelechiidae) en Cartago, Costa Rica. Rev Manejo Integr Plagas 9:12-21

Rodríguez-Falcón M, Bou J, Prat S (2006) Seasonal control of tuberization in potato: conserved elements with the flowering response. Annu Rev Plant Biol 57:151-180. doi:10.1146/ annurev.arplant.57.032905.105224

Sadek MM, Anderson P (2007) Modulation of reproductive behaviour of Spodoptera littoralis by host and non-host plant leaves. Basic Appl Ecol 8:444-452. doi:10.1016/j.baae.2006.08.001

Sánchez JD, López-Ávila A, Rodríguez L (2005) Determinación de las etapas críticas en el desarrollo fenológico del cultivo de la papa Solanum phureja, frente al ataque de la polilla guatemalteca Tecia solanivora (Lepidóptera: Gelechiidae). Agron Colomb 23:230-238

Saveer AM, Kromann SH, Birgersson G et al (2012) Floral to green: mating switches moth olfactory coding and preference. Proc R Soc B Biol Sci 279:2314-2322. doi:10.1098/rspb.2011.2710
Srinivasan R, Talekar NS, Uthamasamy S (2003) Host plant influences on the reproductive behaviour of Tomato fruitworm, Helicoverpa armigera Hubner (Lepidoptera: Noctuidae). Trop Agric Res 15:177-187

Tamiru A, Bruce TJA, Woodcock CM et al (2011) Maize landraces recruit egg and larval parasitoids in response to egg deposition by a herbivore. Ecol Lett 14:1075-1083. doi:10.1111/j.14610248.2011.01674.x

Tasin M, Anfora G, Ioriatti C et al (2005) Antennal and behavioural responses of grapewine moth Lobesia botrana females to volatiles from grapewine. J Chem Ecol 31:77-87. doi:10.1007/ s10886-005-0975-3

Tasin M, Coracini M, Casado D (2007) Synergism and redundancy in a plant volatile blend attracting grapevine moth females. Phytochemistry 68:203-209. doi:10.1016/j.phytochem.2006.10. 015

Theis N (2006) Fragrance of Canada thistle (Cirsium arvense) attracts both floral herbivores and pollinators. J Chem Ecol 32:917-927. doi:10.1007/s10886-006-9051-x

Tingle FC, Heath RR, Mitchell ER (1989) Flight response of Heliothis subflexa (Gn.) females (Lepidoptera: Noctuidae) to an attractant from groundcherry, Physalis angulata L. J Chem Ecol 15:221-231. doi:10.1007/BF02027784

Torres WF, Notz A, Valencia L (1994) Life cycle and other aspects of the biology of Tecia solanivora (Povolny) (Lepidoptera: Gelechiidae) in Tachira state, Venezuela. Bol Entomol Venez 12:95-106

Traynier R (1983) Influence of plants and adult food on the fecundity of the potato moth, Phthorimaeo operculella. Exp Entomol Appl 33:145-154

Wickman P-O, Rutowski RL (1999) The evolution of mating dispersion in insects. Oikos 84:463-472

Xiao C, Gregg PC, Hu W et al (2002) Attraction of the cotton bollworm, Helicoverpa armigera (Hübner) (Lepidoptera: Noctuidae), to volatiles from wilted leaves of a non-host plant, Pterocarya stenoptera. Appl Entomol Zool 37:1-6 